BACTERIOLOGICAL NOMENCLATURE AND TAXONOMY

\title{
THE CORRECT SPELLING OF THE SPECIFIC EPITHET IN THE SPECIES NAME MICROCOCCUS LYSODEIKTICUS FLEMING 1922 Preliminary Statement. File No 6
}

Edited by R. E. Buchanan, Robert S. Breed and S. T. Cowan

The Editorial Board has prepared the frillowing statement for the consideration of the members of the Judici. 1 Commission and in order to secure a preliminary ballot before a formal Opinion is prem pared for final approval The Editorial Board will be pleased to receive comments and criticisms from any person interested.

THE JUDICIAL Commission has been requested to issue an opinion concerning the speiling of the specific epithet in Manoson

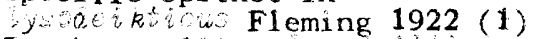
Is the spelling yscactio correct or should the spell be changed the better to con form to the traditional classi cal rules for the translitera tion of Greek into Latin?

The adjective ysole $k$ in is derived from the Greek 286 : setting free disso lution Qderefre abie to show The two stems are joined by the connective vowel

There is no rule or recommenda tion in the International Bac teriological Code of Nomencia ture specifying the exact method of transliterating Greek words into Latin However since tile beginning of modern biologrcai nomenclature transilteration ac cording to classic precedent has been advocated Linnaeus in his Critica Botanica (translation of Sir Arthur Hirt) if 247 put the matter as follows

Moreover in every age it has keen the recognized practice amongst almost all Botanists: and even among the most eloquent Romaris in ancient times. by Pliny and others: to write Greek names in Roman letters. When Greek names are trans 1 iterated in to Latin the equivalents used by the Romans from all time

(1) Fleming Alexander On a remarkable bacteriolytic ele ment found in tissues and secretions Proc Roy Soc Londion Sec B 55:306 317. 822 must be adopted in represent ing the Greek letiers

He gives specific rules for such transliteration; among them and appiscable to this case are the following

The Greek diphthong $\mathrm{C} 6$ be comes occasional iy $\ell$.

Final os becomes ws.

$k$ becomes

Those rules for transliteration are appended to the Zo ological and Botanical Rules of Nomencl ature

An al ternative. nonclassi cal method of transliteration particularly into modern lang uages, is sometimes used as follows

The Greek diphthong 6 becomes $\theta$ :

Final a becomes

Kappa $\approx$ becomes $R$

In the specific epithet jood: $k$ was: the speiling of the first component. conforms to the classic rules The connecting vowei is probably appropriate Concern ing connecting vowels in compount words: Recommendation $27 \mathrm{~h}$ of the International Bacteriolog rcal Code of Nomenclature states In the formation of names or epithets composed of two or several roots taken from Lat in or Greek: the vowel placed between the two roots becomes a connecting vowel in Latin usualiy in Greek usually 0 It is of interest to note however, that the Greeks in forming compounds with 3208 as the frist component used as a connecting vowe 1 and not Probably either or in the Latin transliteration should be regarded as accept able 


\section{INTERNATIONAL BULLETIN}

The classic transliteration yieids the Latin forms lysodicticus or lysiatiticis. The alternative, nonclassic trans. literation would give $\bar{l} y s o \hat{a} e \hat{i} k$ itkos. It would seem that $l_{y}$ soaeikicus is formed in part by following the classic form ula, in part the nonclassic

The rules and recomnendations of the Bacteriological Code that may be pertinent are the follow ing

Five $2 \%$ The original spell. ing of a nane or epithet must be retained, except in the case of a typographical error or of clearly unintentional or tho graplitic erros

There is no evidence in the original pulvication that would scem to warlant the conclusion that the spelling $, 0, k$. is the result of a typographica: error and no warrant therefore for changing the spelling on this basis

Can the spelling ysuaciki bu be regarded as a clearly unin tentional orthographic error"

Note 4 . to Rule 27 reads

Specific and other epitliets and names of Greek origin differing inercly by having Greek and Latin terminations respectuvely are or thograpinic variants Evithets bearing the same meaning and ciffering only slightly 1 n form are considered as orthosraphic variants

It mould seem clear that the spelinges yedoc $k$ the

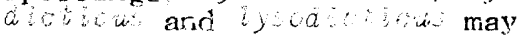
be regarded as or thograrhic variants of the same word But the use by an eutior of an orthographic variant does not prove that the nonclassic trans literation is the result of a clearly unintentional or tho graphic error

Further there secris to be no warrant in the Bacterrological Code for changing a spelling re sulting from the use of non classical transilteration to a spelling in the classical tradi tion The species name
Nicrocoscus lysodenticus is widely accepted and used by bacteriologists

Wouid stability and uniform ity in bacteriological nomen. clature be advanced by approval of one or more of the fol lowing

1 Preparation of an Opinion by the Judicial Cormission to the effect that an author s spellings arising from the ignoring of the classic transliteration from Greek to Latin ate not to be changed unless there is clear evidence of a typographical error or of an unintentional ortho graphic error

2 A clear statement of the rules imposed by classic tradition for the trans literation of Greek to Latin should be prepared to be considered by the Judicial Comnission for recommendations as an appendix to the Interina tional Facteriological Code of Nomenclature

3. A draft shouid be prepared of a Recommendation urg ing ali authors to follow the classic tradition in the transliteration of Greek worós into Latin form for use in naming of taxonomic groups. such draft to be considered by the Judicial Commission for recommendation for inclusion in the Inter national Bacteriologicai Code of Nomenclature

$4 \quad$ A ciraft should be prepared of a Rule authorizing the correction of names de rived from the Greek and not transilterated in accordance with the classic tradition. such ruies to be considered by the Judicial Commission for recommenda tion for inclusion in the International Bacteriolo gical Code of Nomenclature 